\title{
Sequential follow up observations of a patient with rubella associated persistent arthritis
}

\author{
D K Ford, G D Reid, A J Tingle, L A Mitchell, M Schulzer
}

\begin{abstract}
In 1985 a patient was described whose persistent polyarthritis was found to be aetiologically linked to rubella virus infection through the detection of repeated maximal synovial lymphocyte proliferative responses to rubella virus antigen and by isolation of rubella virus from her synovium. Follow up over the succeeding seven years has shown continuing chronic polyarthritis and persistent synovial lymphocyte responses to rubella virus antigen with the additional observation that she has a defective humoral immune response against rubella virus.
\end{abstract}

For many years rubella virus has been aetiologicaly linked to a syndrome of acute polyarthritis occurring particularly in adult women and generally of an acute, self limited nature. Less often, the syndrome may proceed to recurrent or persistent polyarthritis or arthralgia. ${ }^{1}$ Although the acute manifestations of rubella associated arthritis have been well studied, the chronic or recurrent features have been less well recognised or recorded. This paper outlines the clinical and immunological features over a seven year follow up period in a patient previously reported to have chronic arthritis associated with persistent rubella virus infection in synovial tissues and a persistently increased synovial lymphocyte proliferative response to rubella virus. $^{2}$

\section{Case report}

CLINICAL OBSERVATIONS

Department of Medicine, The University of British Columbia, Vancouver,

BC,

Canada

D K Ford

G D Reid

M Schulzer

Departments of

Pediatrics and Pathology,

The University of

British Columbia,

Vancouver,

BC,

Canada

A J Tingle

L A Mitchell

Correspondence to:

Dr D K Ford,

The Arthritis Centre,

895 West 10th Avenue,

Vancouver, BC

V5Z 1E7,

Canada.

Accepted for publication 14 May 1991
Table 1 summarises the clinical features of this patient. For the past 19 years she has had a persistent inflammatory polyarthritis, which has not been associated with rheumatoid factor nor rheumatoid nodules. Radiographs of her hands and knees showed some secondary degenerative changes, moderate osteopenia, and also uniform narrowing of the artricular cartilage of the carpal bones in the left wrist (fig 1). In addition to polyarthritis the patient had an episode of thyroiditis in 1973, and two episodes of ureteric obstruction due to retroperitoneal fibrosis in 1978 and 1986. Medical treatment of her arthritis was complicated by uraemic episodes and moderate hypertension, so that for the past few years treatment had been restricted to enteric coated chlorazanil hydrochloride, low dose prednisone by mouth, and repeated intraarticular corticosteroid injections. She has been able to play a limited 'twilight' golf intermittently up to the present time.
${ }^{3}$ H LYMPHOCYTE STIMULATION ASSAY

The methodology used was the same as described previously. ${ }^{2}$ Ficoll Hypaque separated synovial lymphocytes, at 10000 per well, were incubated in Terasaki plates for seven days in RPMI medium supplemented with $10 \%$ human $A B$ plasma and containing the antigen to be tested, with multiple identical control unstimulated cultures being included in all tests. Standard harvesting methods followed exposure of the cultured lymphocytes to $\left[{ }^{3} \mathrm{H}\right]$ thymidine, $37 \mathrm{kBq}$ per well for four to six hours.

All antigens were crude preparations because it was not known which of the various antigens were relevant. The methods of preparation of the ureaplasmal, chlamydial, candida, salmonella, and other enteric antigens have been described previously. ${ }^{2} 3$ The viral antigens have also been described ${ }^{4}$ and were obtained from Microbiological Associates as the complement fixing antigen, except that up to 1987 the rubella antigen was obtained from Flow Laboratories. In 1989 and 1990, two additional viral antigens were routinely included: Herpesvirus hominis and a trivalent influenza A, B, C, antigen, also obtained from Microbiological

Table I Summary of clinical features

\begin{tabular}{|c|c|c|}
\hline Date & $\begin{array}{l}\text { Age } \\
\text { (years) }\end{array}$ & Clinical manifestations and findings \\
\hline 1959 & 41 & $\begin{array}{l}\text { Contracted fever, malaise, rash, and enlarged } \\
\text { cervical glands from son aged 12; con- } \\
\text { sidered to be rubella, but no medical } \\
\text { observation and no complications }\end{array}$ \\
\hline 1971 & 53 & $\begin{array}{l}\text { Onset of recurrent subacute arthritis of both } \\
\text { knees }\end{array}$ \\
\hline 1973 & 55 & $\begin{array}{l}\text { Diagnosed as having Hashimoto's thyroiditis; } \\
\text { treated with thyroxine and subsequently } \\
\text { had no further thyroid problems }\end{array}$ \\
\hline 1976 & 58 & $\begin{array}{l}\text { Treated by a rheumatologist for recurrent } \\
\text { variable arthritis of both knees }\end{array}$ \\
\hline 1978 & 60 & $\begin{array}{l}\text { Became uraemic and was diagnosed as having } \\
\text { retroperitoneal fibrosis with ureteric } \\
\text { obstruction; was treated successfully by } \\
\text { abdominal surgery and prednisone }\end{array}$ \\
\hline 1980 & 62 & $\begin{array}{l}\text { Came under treatment by a second } \\
\text { rheumatologist (GDR), who has followed } \\
\text { her up over the subsequent ten years, } \\
\text { during which variable subacute to chronic } \\
\text { inflammatory arthritis of knees, elbows, } \\
\text { wrists, ankles, and several finger proximal } \\
\text { interphalangeal joints has persisted, } \\
\text { without rheumatoid nodules and without } \\
\text { rheumatoid factor }\end{array}$ \\
\hline 1983 & 65 & $\begin{array}{l}\text { Synovial lymphocyte studies showed } \\
\text { maximum stimulation by rubella antigen, } \\
\text { compared with } 17 \text { other microbiological } \\
\text { antigens; consequent virological investiga- } \\
\text { tions showing rubella virus in synovial } \\
\text { fluid, as reported previously }\end{array}$ \\
\hline 1986 & 68 & $\begin{array}{l}\text { Right nephrectomy and ureteric reimplanta- } \\
\text { tion for recurrence of retroperitoneal } \\
\text { fibrosis }\end{array}$ \\
\hline 1990 & 72 & $\begin{array}{l}\text { Most recent observations show continued } \\
\text { variable polyarthritis of the same joints, } \\
\text { with the knees causing - most functional } \\
\text { disability and requiring repeated corti- } \\
\text { costeroid injections during exacerbations; } \\
\text { radiographs of the hands are shown in fig } 1 \text {. }\end{array}$ \\
\hline
\end{tabular}




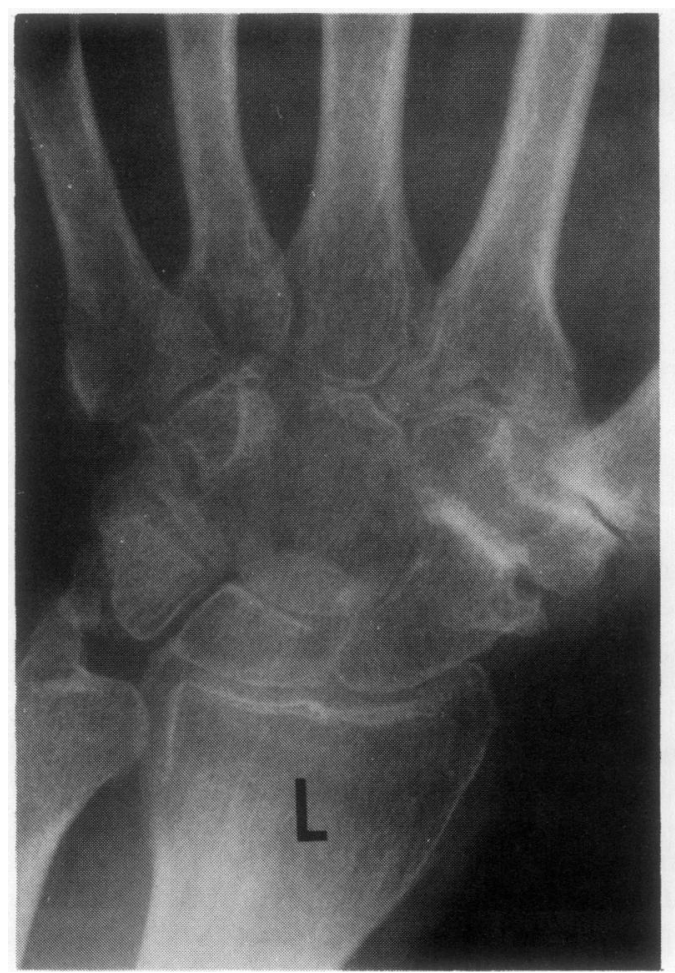

Figure 1 Radiographs of the patient's wrists in 1990.

Associates. In 1990 tuberculin and a parvovirus antigen were used. The tuberculin was obtained from Connaught Laboratories as PPD Tubersol 250 , and added to the cultures in six threefold dilutions to give from 8.3 to 0.03 units per well. The parvovirus antigen was supplied as the B 19 capsid antigen prepared from the 3-11-5 Chinese hamster ovary cell line, and diluted to give 0.5 , 1.6 , and $5 \mathrm{ng}$ per Terasaki well. All antigens were routinely used in three serial threefold dilutions $(1 / 3,1 / 9,1 / 27)$, and initially triplicate, but since 1989 quadruplicate, replicates were set up for each antigen dilution.

Data are shown as the mean of the counts per minute obtained from the antigen dilution giving the maximum response, the mean counts per minute of the unstimulated synovial lymphocytes being included in the barographs. The data were previously expressed as stimulation indices. ${ }^{2}$ The triplicate or quadruplicate counts per minute of the maximum antigen response were compared with those of the next highest response using the two tailed $t$ test. In fig 2 an asterisk shows the responses with $p$ values $<0.05$.

Figure 2 shows the $\left[{ }^{3} \mathrm{H}\right]$ thymidine uptake counts in response to antigenic stimulation by 22 microbiological antigens, observed in 16 evaluations over a seven year period from 1983 to 1990. Counts derived from unstimulated (control) synovial lymphocytes are shown in the left hand column. The response to rubella antigen was greatest in 13 of the 16 studies and, on five occasions, the application of the two tailed $t$ test to the replicate counts of the rubella response versus the second highest antigen responses gave $p$ values $<0.05$, as indicated by the asterisk in the rubella columns.

In 1983 and 1984 the synovial lymphocytes also responded to cytomegalovirus, but the

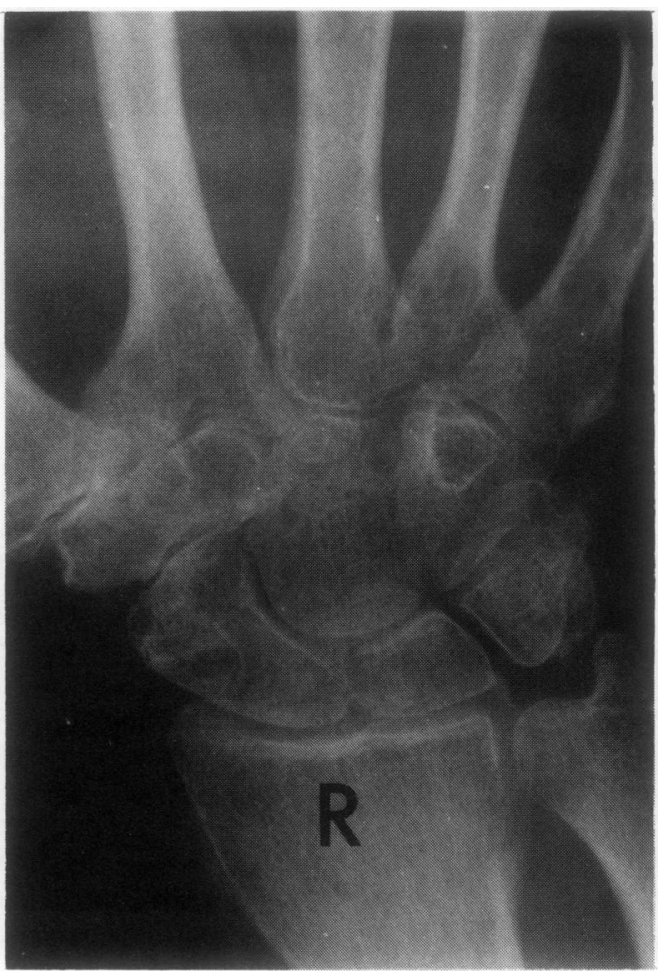

response disappeared in later years. From 1988 to 1990 a herpes simplex antigen was included in the testing and synovial lymphocytes were clearly stimulated by this antigen; however, in the three most recent tests the rubella response was statistically greater. In 1990, testing against PPD Tubersol and a parvovirus antigen was performed, but no significant responses were detected.

\section{MEASUREMENT OF ANTIBODY TO RUBELLA}

ANTIGENS

Antibodies of the IgG class directed to whole rubella virus, rubella virus major structural proteins (the envelope glycoproteins E1 and E2, and capsid protein, $\mathrm{C}$ ) and an antigenic subregion of $\mathrm{El}$ represented by a synthetic peptide were measured by enzyme linked immunosorbent assay (ELISA) or immunoblot techniques as described in the following section.

Whole rubella virus ELISA assays were performed as described previously. ${ }^{6}$ Briefly, rubella virus (M33 strain) harvested from Vero cell culture and resuspended in $0.5 \%$ Triton X 100 in phosphate buffered saline (PBS, pH $7 \cdot 2-7 \cdot 4$ ) was optimally diluted in $0.1 \mathrm{~mol} / \mathrm{l}$ carbonate buffer ( $\mathrm{pH} 9.6$ ) and coated onto ELISA microplates by overnight incubation at $4^{\circ} \mathrm{C}$. After washing the plates in PBS containing $0.5 \%$ Tween 20 (PBST), dilutions of serum from the patient or of reference standard serum were added to the wells and incubated at $37^{\circ} \mathrm{C}$ for one hour to allow specific antibodies to adhere to the viral proteins. After washing the plates with PBST, bound specific antibodies were detected by the addition of alkaline phosphatase conjugated goat antihuman IgG (Fc specific) followed by one hour of incubation at $37^{\circ} \mathrm{C}$. After washing the plates with PBST, 


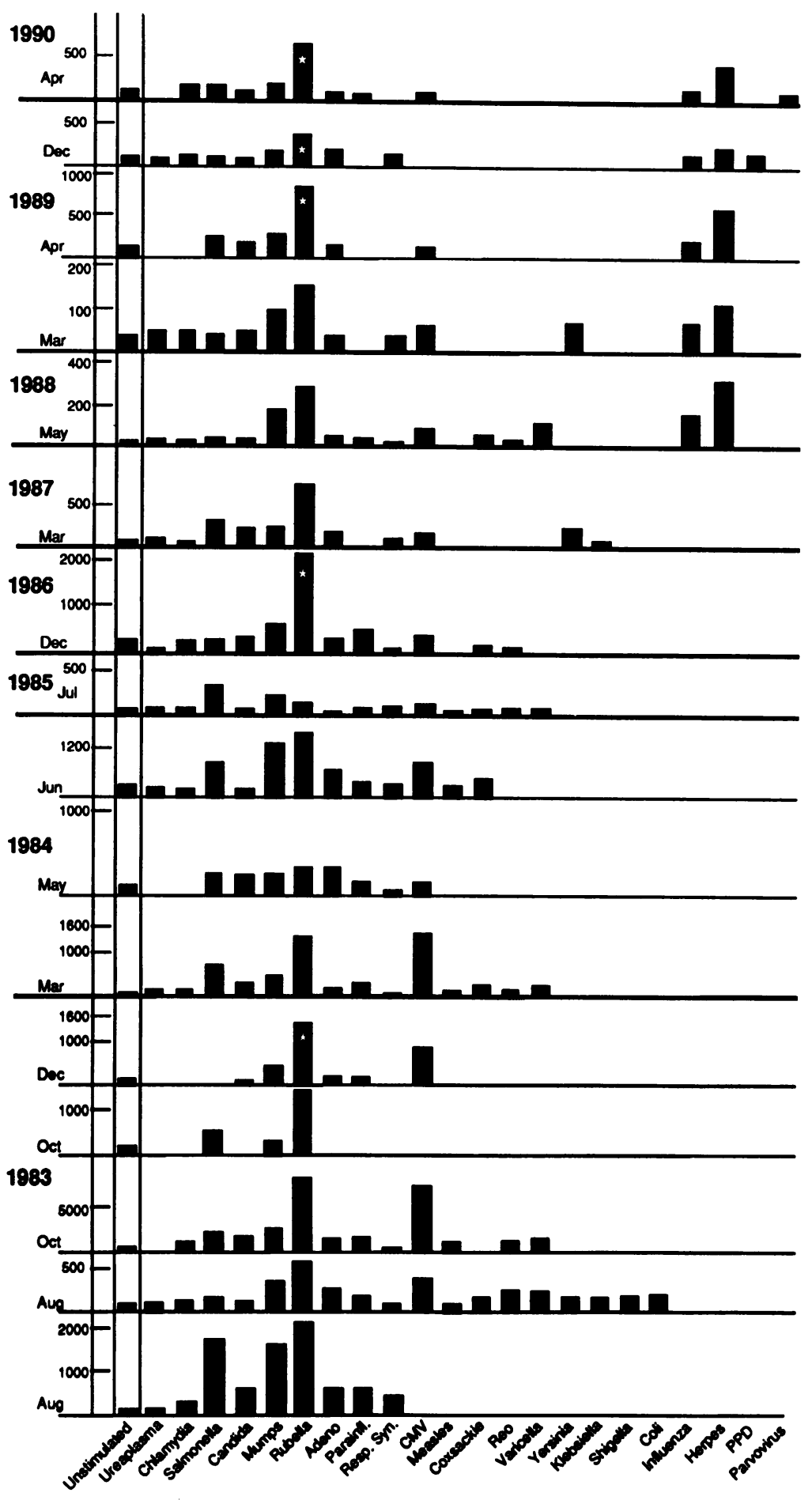

Figure $2\left[{ }^{3} \mathrm{H}\right]$ Thymidine uptake counts in response to antigenic stimulation by microbiological antigens. coated with a synthetic peptide thought to represent a neutralisation domain on the rubella virus El protein (M. Zrein, IAF BioChem International, personal communication). Peptide coated microplate wells were subsequently exposed to 1:50 dilutions of patient or reference $(15 \mathrm{IU} / \mathrm{ml})$ or positive and negative control serum samples and incubated for 30 minutes at room temperature. After washing the plates with PBST, bound specific antibodies were detected by the sequential addition of horseradish peroxidase conjugated antihuman IgG antiserum and enzyme substrate (tetramethylbenzidine/hydrogen peroxide) with 30 minute incubations and washing with PBST between the addition of the anti-human IgG antibody and substrate. After stopping the reaction by the addition of $1 \mathrm{M} \mathrm{HCl}, \mathrm{A}_{450}$ was determined for each well using a microplate reader. Levels of peptide specific antibody in patient samples were calculated as:

$$
\text { Ratio }=\frac{A_{450} \text { patient sample }}{A_{450} \text { reference }}
$$

Antibody $(\mathrm{IU} / \mathrm{ml})=\mathrm{ratio} \times 15 \mathrm{IU} / \mathrm{ml}$

The results are expressed in $\mathrm{IU} / \mathrm{ml}$.

Immunobilot assays were performed as described by Towbin et al. ${ }^{7}$ Briefly, purified rubella virus (M33) was electrophoretically separated by sodium dodecyl sulphate polyacrylamide gel electrophoresis under nonreducing conditions. The separated proteins were transferred electrophoretically onto nitrocellulose membranes which were then blocked by incubation with $2 \%$ milk powder in PBS. The membranes were exposed to dilutions of patient serum or negative and positive control serum samples and washed in PBS containing $0.5 \%$ Tween 20 . Bound specific antibodies were detected by the sequential addition of alkaline phosphate conjugated goat antihuman IgG, followed by washing in PBS-Tween, and incubation with enzyme substrate (nitroblue tetrazolium/5-bromo-4-chloroindolyl phosphate in TRIS buffer, pH 9.5). Specific antibodies were detected by the appearance of a coloured band in the molecular weight range anticipated for the $\mathrm{E} 1, \mathrm{E} 2$, or $\mathrm{C}$ proteins, as observed on membranes incubated with positive control serum samples.

\section{ANTIBODY RESPONSES TO RUBELLA VIRUS}

Table 2 summarises the humoral immune responses to rubella virus measured over the last three years of the follow up period. In general, IgG antibody levels measured by whole rubella virus ELISA in serum or plasma samples paralleled those measured in synovial fluid samples collected at the same time. All values were well above the established minimum protective levels of $15 \mathrm{IU} / \mathrm{ml}$, although a progressive decline in antibody levels was observed over the time period studied.

In sharp contrast, levels of antibody measured by the neutralisation domain peptide ELISA were low, being below or barely above those measured in the negative control samples. Although protective antibody levels have not 
Table 2 Antibody responses to rubella virus

\begin{tabular}{|c|c|c|c|c|c|c|}
\hline \multirow[t]{2}{*}{$\begin{array}{l}\text { Date of } \\
\text { study }\end{array}$} & \multicolumn{2}{|c|}{$\begin{array}{l}\text { Whole rubella virus } \\
\text { IgG ELISA* }\end{array}$} & \multicolumn{2}{|c|}{$\begin{array}{l}\text { El peptide } \\
\text { IgG ELISAt }\end{array}$} & \multicolumn{2}{|c|}{$\begin{array}{l}\text { Rubella IgG } \\
\text { immunoblot }\end{array}$} \\
\hline & $\begin{array}{l}\text { Serum } \\
\text { sample }\end{array}$ & $\begin{array}{l}\text { Synovial } \\
\text { fluid } \\
\text { sample }\end{array}$ & $\begin{array}{l}\text { Serum } \\
\text { sample }\end{array}$ & $\begin{array}{l}\text { Synovial } \\
\text { fluid } \\
\text { sample }\end{array}$ & $\begin{array}{l}\text { Serum } \\
\text { sample }\end{array}$ & $\begin{array}{l}\text { Synovial } \\
\text { fluid } \\
\text { sample }\end{array}$ \\
\hline $\begin{array}{l}18 \text { March } 1987 \\
6 \text { August } 1988 \\
\text { 27 June } 1989 \\
6 \text { October } 1989 \\
23 \text { April } 1990 \\
23 \text { July } 1990\end{array}$ & $\begin{array}{r}123 \cdot 4 \\
126 \cdot 4 \\
98 \cdot 7 \\
65 \cdot 5 \\
72 \cdot 3 \\
28 \cdot 0\end{array}$ & $\begin{array}{r}84.7 \\
111.6 \\
141.9 \\
55 \cdot 4 \\
88.0 \\
13.2\end{array}$ & $\begin{array}{l}5 \cdot 4 \\
5 \cdot 6 \\
4 \cdot 2 \\
3 \cdot 5 \\
1 \cdot 2 \\
4 \cdot 1\end{array}$ & $\begin{array}{l}5 \cdot 5 \\
4 \cdot 1 \\
3 \cdot 1 \\
2 \cdot 4 \\
1 \cdot 8 \\
2 \cdot 2\end{array}$ & $\begin{array}{l}\text { ND } \ddagger \\
\text { ND } \\
\text { ND } \\
\text { ND } \\
\text { E1, E2 } \\
\text { E1, E2 }\end{array}$ & $\begin{array}{l}\text { ND } \\
\text { ND } \\
\text { ND } \\
\text { ND } \\
\text { E1, E2 } \\
\text { E1, E2 }\end{array}$ \\
\hline
\end{tabular}

${ }^{*}$ Results given as IU $/ \mathrm{ml}$. Negative $<15 \mathrm{IU} / \mathrm{ml}$.

tResults given as IU/ml. Negative $<15 \mathrm{IU} / \mathrm{ml}$.

$\Varangle \mathrm{ND}=$ not done. persistent infection of synovial tissues with rubella virus and evidence of persistent maximal proliferative responses of synovial lymphocytes to rubella virus.

Follow up observations of this patient have therefore shown the persistence of her chronic inflammatory polyarthritis for 19 years, and also the persistence of her maximum synovial lymphocyte reactivity to rubella antigen over a period of seven years.

Screening tests for total rubella specific antibody (whole rubella virus IgG ELISA) showed low to moderate levels of specific antibody in serum and synovial fluid. Antibody responses directed to each of the three major structural proteins of rubella virus, E1, E2, and C were assessed by immunoblotting, which detected the presence of specific IgG directed against the envelope glycoproteins (E1 and E2) but none against capsid protein (C). Identical patterns of reactivity were observed in serum and synovial fluid. Of particular interest in this patient was the extremely low levels of antibody reactive with a synthetic peptide which may represent a neutralisation domain on rubella virus $\mathrm{E} 1$ protein. The absence of detectable antibody by this technique, despite the observation of levels of antibody directed to other rubella virus structural proteins as shown by immunoblot, suggests that the patient may have been unable to mount a protective serological response to rubella virus and that a defective immune response may have contributed to the establishment of rubella virus persistence in this subject. It is expected that the further development of antigen specific immunological techniques will clarify the pathogenesis of the arthritis and its relation to rubella infection.

This work was supported by funds provided by the Mary Pack Fund, the Beta Sigma Phi, Bill and Betty McQueen, Medical Research Council of Canada. The parvovirus antigen was kindly supplied by Dr Collett, Molecular Vaccines Inc, Gaithersburg, MD, USA.

1 Tingle A J, Allen M, Petty R E, Kettyls G D, Chantler J K. Rubella-associated arthritis. I. Comparative study of joint manifestations associated with natural rubella infection and RA 27/3 rubella immunization. Ann Rheum Dis 1986; 45: RA 27/3.

2 Chantler J K, da Roza D M, Bonnie M E, Reid G D, Ford DK. Sequential studies on synovial lymphocyte stimulation by rubella antigen, and rubella virus isolation in an adult with persistent arthritis. Ann Rheum Dis 1985; 44: 564-8.

3 Ford D K, da Roza D M, Schulzer M. Lymphocytes from the site of disease but not blood lymphocytes indicate the cause of arthritis. Ann Rheum Dis 1985; 44: 701-10.

4 Ford D K, da Roza D M. Observations on the responses of synovial lymphocytes to viral antigens in rheumatoid arthritis and Reiter's syndrome. $\mathcal{f}$ Rheumatol 1983; 10: 643-6.

5 Ford D K, da Roza D M. Further observations on the response of synovial lymphocytes to viral antigens in rheumatoid arthritis. $\mathcal{F}$ R heumatol 1986; 13: 113-7.

6 Tingle A J, Chantler J K, Kettyls G D, Larke R P B, Schulzer $M$. Failed rubella immunization in adults: association with immunologic and virological abnormalities. tion with immunoct Dis 1985; 151: 330-6.

7 Towbin H, Stahelin T, Gordon J. Electrophoretic transfer of proteins from polyacrylamide gels to nitrocellulose sheets. Proc Natl Acad Sci USA 1979; 76: 4350-4. 